\title{
Mathematical correlation between villus height and the nutritional state in Sprague-Dawley rats
}

\author{
J L Zambonino Infante, J M Rouanet, P Besançon
}

\begin{abstract}
Three different experiments were carried out on growing male Sprague-Dawley rats. In the first experiment, dietary nitrogen was given in casein at four different protein values ranging from 5 to $16 \%$. Rats were fed ad libitum for 21 days. In the second experiment, which lasted 17 days, animals were given three diets that differed in the molecular form of the nitrogen supply - that is, proteins or peptides. The protein value $(\mathbf{N} \times 6 \cdot 25)$ was $10 \%$ in each diet. In the third experiment, malnourished rats were refed diets with a protein value of $15 \%$ $(\mathbf{N} \times 6 \cdot 25)$ for eight days. The dietary nitrogen was either in the form of protein, peptide, or amino acid. Body weight was recorded daily. At the end of each experiment the intestinal villus height was measured by light microscopy. Data were statistically analysed by Exner's coefficient. The results assessed the validity of the correlation between villus height and gain in body weight.

(Gut 1993; 34: 1066-1068)
\end{abstract}

One of the important problems in nutrition is to determine how animals respond and adapt to a new diet. They must adapt to various nutritional conditions, particularly to the value, nature, and molecular form of the nitrogen in the diet to survive. The quality of nitrogen supply in foodstuffs is generally assessed by nutritional indices such as gain in body weight and how effectively protein is digested. Morphological measurements and enzyme activities carried out on intestinal mucosa are another good method of assessing dietary nitrogen quality. Changes in villus and microvillus height are relevant to such an adaptive response. ${ }^{1-4}$ Some authors ${ }^{5}$ have emphasised the use of mucosal enzyme activities - that is, those of disaccharidases and leucine aminopeptidase - as indicators of dietary protein quality. On the other hand, assessment of morphological changes has more often been used in the diagnosis and assessment of intestinal pathology $y^{6-10}$ or in studies on intestinal development during fetal life. ${ }^{11}$ Finally, King et al,${ }^{12}$ have pointed out a trophic effect of the dietary nitrogen value on mucosal growth, triggering off an increase in villus height.

The villus height depends upon two factors; firstly on cellular multiplication and differentiation from the crypts; and secondly on the migration of mature cells along the villus axis, accompanied by the cellular shedding from the apex. The regulation of these factors is widely considered to be the way in which the small intestine adapts to nutritional demands. ${ }^{13-17}$ Nevertheless it remains to be verified whether villus height is relevant to the previous dietary history - that is, nitrogen supply quality - and whether it depends on body weight at the time it is measured.

This study aimed at working out a simple mathematical correlation between the villus height and gain in body weight in rats adapted to different experimental conditions. ${ }^{4} 1819$

\section{Methods}

ANIMALS AND DIETS

Three experiments were carried out. These differed not only in duration but also in the molecular form in which the nitrogen was supplied (protein, peptide, or amino acid). These experiments were performed on SpragueDawley rats (Iffa Credo, France).

\section{Experiment 1}

Growing male rats weighing mean (SEM) 114 (2) $\mathrm{g}$, were divided into four equal groups of six animals according to the average body weight. They were fed ad libitum isocaloric diets with increasing protein values $(5,8,10 \cdot 5$, and $16 \%)$; the dietary nitrogen was supplied by casein. The composition of the diets has been previously published. ${ }^{4}$ The experiment lasted for 21 days.

\section{Experiment 2}

Fifteen male rats, 25 days old, and weighing 80 (4) $\mathrm{g}$ were divided into three equal groups. They were fed isocaloric and isonitrogenous diets $(1.6 \% \mathrm{~N}$ - that is, $10 \%$ concentration protein) containing either casein (control group), bovine plasma protein, or an enzymatic hydrolysate of these proteins containing $75 \%$ of dipeptides and tripeptides. The experiment was carried out over 17 days. Experimental diets have already been described. ${ }^{18}$

\section{Experiment 3}

Twenty growing male rats were submitted to 15 days protein malnutrition $(2.4 \%$ protein concentration, supplied by casein) and were then randomly distributed to four equal groups of five animals weighing $105(5) \mathrm{g}$. On day 16, they were given isocaloric and isonitrogenous diets $(2 \cdot 4 \%$ $\mathrm{N}$ - that is, $15 \%$ protein value) containing either casein, blood protein, an enzymatic hydrolysate of these proteins (see experiment 2) or an amino acid mixture equivalent to blood proteins, as the sole nitrogen source. Twenty other rats were submitted to a 15 day period of protein-calorie malnutrition and were then distributed to four equal groups of five animals (81 (2) g) and subjected to an identical diet. The refeeding 
Experimental data and characteristics of the estimations given by the model (values, mean $(S E M))$

\begin{tabular}{|c|c|c|c|c|c|c|c|}
\hline $\begin{array}{l}\text { Point } \\
\text { no }\end{array}$ & $\begin{array}{l}\text { Experiment } \\
\text { number }\end{array}$ & $\begin{array}{l}\text { Body weight } \\
\text { gain (g/day) }\end{array}$ & $\begin{array}{l}Y \exp \\
(\mu m)\end{array}$ & $\begin{array}{l}Y t h \\
(\mu m)\end{array}$ & $\begin{array}{l}\text { Yexp-Yth } \\
(\mu m)\end{array}$ & $\begin{array}{l}\text { Y reliable } \\
\text { interval } \\
(p<0.05)\end{array}$ & $\begin{array}{l}\text { Body } \\
\text { weight } \\
(\mathrm{g})\end{array}$ \\
\hline $\begin{array}{r}1 \\
2 \\
3 \\
4 \\
5 \\
6 \\
7 \\
8 \\
9 \\
10 \\
11 \\
12 \\
13 \\
14 \\
15 \\
16\end{array}$ & $\begin{array}{l}3 \\
3 \\
2 \\
1 \\
3 \\
3 \\
3 \\
3 \\
1 \\
2 \\
2 \\
1 \\
3 \\
1 \\
3 \\
3 \\
3 \\
3\end{array}$ & $\begin{array}{l}0.06(0.00) \\
1.40(0.20) \\
1.77(0.20) \\
1.86(0.28) \\
2.20(0.40) \\
3.30(0.40) \\
3.30(0.40) \\
3.32(0.40) \\
3.78(0.52) \\
4 \cdot 18(0.27) \\
4.54(0.38) \\
6.10(0.20) \\
6.15(0.42) \\
7.40(0.40) \\
8.70(0.10) \\
9.10(0.40)\end{array}$ & $\begin{array}{l}389 \cdot 7 \\
484 \cdot 9 \\
443 \cdot 0 \\
488 \cdot 0 \\
508 \cdot 4 \\
563 \cdot 7 \\
526 \cdot 3 \\
550 \cdot 0 \\
593 \cdot 0 \\
568 \cdot 0 \\
573 \cdot 0 \\
575 \cdot 9 \\
581 \cdot 0 \\
651 \cdot 4 \\
603 \cdot 8 \\
628 \cdot 6\end{array}$ & $\begin{array}{l}364 \cdot 9 \\
469 \cdot 3 \\
488 \cdot 2 \\
492 \cdot 4 \\
507 \cdot 0 \\
543 \cdot 6 \\
543 \cdot 6 \\
544 \cdot 1 \\
556 \cdot 0 \\
565 \cdot 0 \\
572 \cdot 4 \\
597 \cdot 7 \\
598 \cdot 4 \\
613 \cdot 2 \\
625 \cdot 2 \\
628 \cdot 4\end{array}$ & $\begin{array}{r}24 \cdot 78 \\
15 \cdot 59 \\
-45 \cdot 22 \\
-4 \cdot 40 \\
1 \cdot 45 \\
20 \cdot 13 \\
-17 \cdot 28 \\
5 \cdot 87 \\
37 \cdot 05 \\
2 \cdot 97 \\
0 \cdot 60 \\
-21 \cdot 84 \\
-17 \cdot 41 \\
38 \cdot 24 \\
-21 \cdot 42 \\
0 \cdot 19\end{array}$ & $\begin{array}{l}362 \cdot 89-366 \cdot 94 \\
451 \cdot 20-487 \cdot 40 \\
470 \cdot 15-506 \cdot 29 \\
474 \cdot 45-510 \cdot 35 \\
489 \cdot 68-524 \cdot 21 \\
529 \cdot 30-557 \cdot 86 \\
529 \cdot 30-558 \cdot 36 \\
529 \cdot 90-558 \cdot 36 \\
542 \cdot 61-569 \cdot 28 \\
552 \cdot 10-577 \cdot 96 \\
559 \cdot 51-585 \cdot 28 \\
582 \cdot 15-613 \cdot 33 \\
582 \cdot 68-614 \cdot 14 \\
593 \cdot 69-632 \cdot 63 \\
601 \cdot 76-648 \cdot 68 \\
603 \cdot 77-653 \cdot 05\end{array}$ & $\begin{array}{l}107(3) \\
116(3) \\
112(4) \\
157(6) \\
123(6) \\
107(5) \\
131(2) \\
183(8) \\
149(8) \\
155(5) \\
208(8) \\
130(3) \\
248(8) \\
140(6) \\
175(6) \\
153(5)\end{array}$ \\
\hline
\end{tabular}

periods lasted for eight days. The composition of the diets has been reported. ${ }^{19}$ In each experiment the animals were kept in individual metabolic cages at a constant temperature $\left(25(1)^{\circ} \mathrm{C}\right)$ with a 12 hour dark-light period and free access to water.

\section{EXPERIMENTAL DESIGN}

At the end of each experiment rats were killed by cervical dislocation and the abdomen was opened immediately. The procedure described below was carried out at $4^{\circ} \mathrm{C}$. The intestine was removed, intact from the pylorus to the ileocecal valve, and a standard jejunal segment consisting of the portion between 30 and $45 \mathrm{~cm}$ distal to the Treitz's ligament was excised. After flushing with ice cold saline, $1 \mathrm{~cm}$ specimens were taken from the beginning of the segment in all cases, fixed in Bouin's solution, embedded in paraffin wax, cut perpendicular to the longitudinal axis, and stained with haematoxylin and eosin. The length of the villi was measured by light microscopy (Nikon 104 equipped with a projector). All rats were killed between 1400 and 1600 hours to prevent circadian variations.

\section{CALCULATIONS AND STATISTICS}

Several regression models were tested. Their validity was evaluated by the following: (a) analysis of variance (ANOVA), which gives

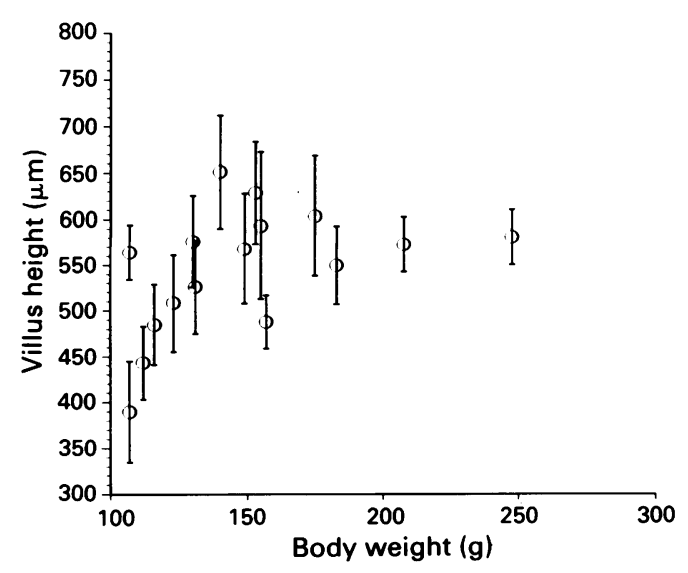

Figure 1: Relation between body weight and villus height in rats at the end of each experiment.

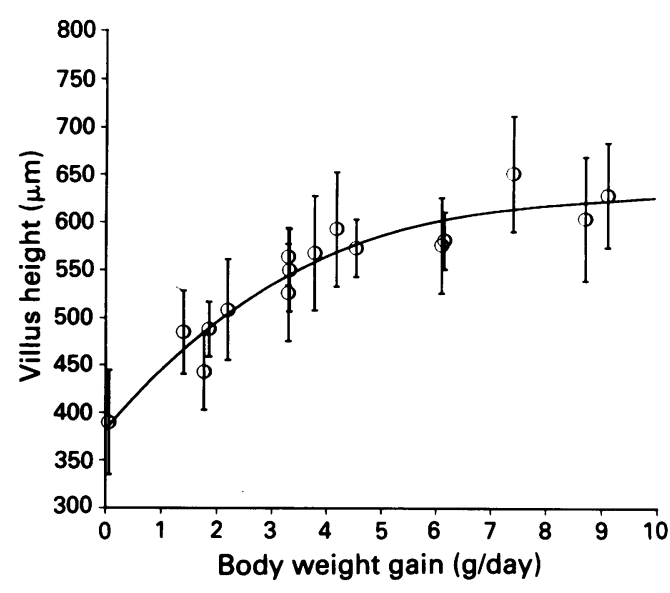

Figure 2: Relation between body weight gain and villus height measured in each dietary group at the end of each experiment.

the significant difference in regression on the horizontal or vertical axis. The regression will be greater as the difference becomes significant; or (b) the coefficient of correlation, which expresses the intensity of the relation between the experimental points as follows:

$$
\mathrm{R}^{2}=1-\frac{\Sigma(\mathrm{Yexp}-\mathrm{Yth})^{2}}{\Sigma(\mathrm{Yexp}-\mathrm{Ym})^{2}}
$$

(c) Exner's coefficient, ${ }^{20}$ which assesses the degree of adjustment of an experimental distribution to fit a theoretical model. This coefficient is more sensitive than the correlation insofar as it tests the theory as a whole - that is, both the form of empirical function and the values of the parameters. The model will be valid if $\emptyset<0.5$; Exner's coefficient is calculated using the following formula:

$$
\emptyset^{2}=\frac{\Sigma(\mathrm{Yexp}-\mathrm{Yth})^{2}}{\Sigma(\mathrm{Yexp}-\mathrm{Ym})^{2}} \times \frac{\mathrm{n}}{\mathrm{n}-\mathrm{p}}
$$

Where: Yexp=experimental height; Yth= theoretical villus height; $Y m=$ villus height average; $\mathrm{n}=$ data couple number $(\mathrm{x}, \mathrm{y}) ; \mathrm{p}=$ adjustable parameters number.

And where: $\emptyset<0.02=$ very good agreement; $\emptyset<0 \cdot 1=$ good agreement; $\emptyset<0 \cdot 2=$ fair agreement; $\emptyset>0 \cdot 5=$ pattern to dismiss.

\section{Results and discussion}

The Table shows experimental data. Figure 1 shows possible association between animal body weight and villus height. The ANOVA for the different models of regression tested ${ }^{2122}$ is very explicit. The points distribution is not significantly different from a horizontal line and a relation between the villus height and the body weight cannot therefore be considered in this body weight range. On the other hand Fig 2 shows a well ordered point repartition, significantly different from a horizontal line; the selected mathematical example for this repartition is a hyperbolic graph ${ }^{212}$ described by the following equation:

$$
\mathrm{Y}=\frac{\mathrm{aX}}{\mathrm{b}+\mathrm{X}}+\mathrm{c}
$$

Where: $\mathrm{Y}=$ villus height $(\mu \mathrm{m}) ; \mathrm{X}=$ body weight 
gain (g/day); $a=365 \cdot 33 ; b=3 \cdot 20 ; c=358 \cdot 20$ and with: $R=0.944$ and $\emptyset=0.366$

With such indicators $(R$ and $\emptyset)$ the hyperbolic model is well validated. The coefficient of correlation value is good, considering that we tried to get a mathematical relation from a physiological response. Exner's coefficient confirmed the pattern validity as its value shows fair agreement between the theoretical equation and the experimental data points. Moreover, this model has the advantage of giving, by means of a simple calculation: (i) a minimal villus height (about $358 \mu \mathrm{m}$ ), which related experimentally to protein malnutrition, (ii) a limit to villus growth reaching about $710 \mu \mathrm{m}$ as maximum height related experimentally to a protein value of $20 \%$, or higher. This study justified the use of villus height as an indicator of the nutritional state in rats. Indeed, villus height was mathematically correlated to daily body weight gain, another indicator of nutritional state, and was independent of body weight, which is an indicator of the state of development. It is proposed that this is a new, complementary criterion to use.

The authors acknowledge Dr Christian AIMAR for his helpful criticism in the statistical processing of experimental data.

1 Syme G, Smith MW. Intestinal adaptation to protein deficiency. Cell Biol Intern Rep 1982; 6: 573-8.

2 Dowling RH. Small bowel adaptation and its regulation. Scand f Gastroenterol 1982; 17 (suppl 74): 53-74.

3 Williamson NCR, Chir M. Intestinal adaptation. Structural, functional and cytokinetic changes. N Englf Med 1978; 298 1393-402.

4 Zambonino Infante JL, Rouanet JM, Caporiccio B, Besançon $P$. Effects of dietary protein and carbohydrate level in the rat small intestine: enzymic, histological and electron microscopy studies. Nutr Rep Int 1989; 40: 313-21.

5 Kimura T, Seto A, Kato T, Yoshida A. Effect of dietary amin acids and protein on jejunal dissacharidase and leucine amino peptidase activities of rats. Nutr Rep Int 1977; 16: 621-30.
6 Howdle PD, Corazza GR, Bullen AW, Losowsky MS. Gluten sensitivity of small intestinal mucosa in vitro: quantitative sensitivity of small intestinal mucosa in vitro: quantitative assessment

7 Williams EW, Wood HP. The effect of wheat proteins on rat intestinal villi. IRCS Med Sci 1981; 9: 23-4.

8 Challacombe DN, McDonald DT, Wheeler EE. A quantitative assessment of jejunal villous damage in coeliac disease using the mucosal index. Hepatogastroenterology 1983; 30 113-5.

9 Sjölander A, Magnusson KE, Latkovic S. Morphological changes of rat small intestine after short time exposure to concanavalin A or wheat germ agglutinin. Cell Struct Funct 1986; 11: 285-93.

10 Davidson AGF, Bridges MA. Coeliac disease: a critical review of aetiology and pathogenesis. Clin Chim Acta 1987; 163: $1-40$.

11 King YS, Paterson JYF, Peacock MA, Smith MW, Syme G Effect of diet upon enterocyte differentiation in the rat Effect of diet upon enterocyte differ

12 Trahair JF, Robinson PM. An integrated model for intestinal development in the fetal sheep. Reprod Nutr Dev 1987; 27 849-57.

13 Deo MG, Ramalingaswami V. Reaction of the small intestin to induced protein malnutrition in rhesus monkeys. A study of cell population kinetics in the jejunum. Gastroenterology 1965; 49: 150-7.

14 Aldewachi HS, Wright NA, Appleton DR, Watson AJ. The effect of starvation and refeeding on cell population kinetics in the rat small bowel mucosa. 7 Anat 1975;119: 105-21.

15 Hagemann RF, Stargand JJ. Fasting and refeeding: cell kinetic response of jejunum, ileum and colon. Cell Tissue Kinet 1977; 10: 3-14.

16 Koga A, Kimura S. Influence of restricted diet on the cell cycle in the crypt of mouse intestine. F Nutr Sci Vitaminol 1980 26: 33-8

17 Mish DW. Intestinal microvilli: response to feeding and fasting. Eur F Cell Biol 1980; 21: 269-79.

18 Rouanet JM, Zambonino Infante JL, Caporiccio B, Pejoan C Nutritional value and intestinal effects of dipeptides and tripeptides. Comparison with their issuing bovine plasm protein in rats. Ann Nutr Metabol 1990; 34: 175-82

19 Zambonino Infante JL, Rouanet JM, Caporiccio B, Pejoan C Besancon $P$. Nutritional rehabilitation of malnourished rats by di and tripeptides: nitrogen metabolism and intestina response. F Nutr Biochem 1992; 3: 285-90.

20 Exner O. Additive physical properties. I. General relationships and problems of statistical nature. Collection of $C$ zechoships and problems of statistical nature. Collection of
slovak Chemical Communications 1966; 31: 3222-51.

21 La regression; nouveaux regards sur une ancienne méthode statistique. In: Tomassone R, Lesquoy E, Miller C, eds. Actualités Scientifiques et agronomiques de l'INRA, 13. Paris: Masson, 1983.

22 Introduction aux modèles mathématiques en biologie. In olivet E, ed. Actualités Scientifiques et Agronomiques de 'INRA, 11. Paris: Masson, 1983. 